Vol. 6, No. 1, 2021

\title{
IMPROVEMENT OF PURIFICATION TECHNOLOGY OF THE LIQUID WASTE FROM FERMENTATION PRODUCTION
}

\author{
Galina Krusir, Olga Sagdeeva, Alfred Tsykalo, Yuliia Vilhovska, Tatyana Shpyrko \\ Odessa National Academy of Food Technologies, \\ 112, Kanatna Str., Odessa, 65039, Ukraine \\ sagolanis@ukr.net
}

https://doi.org/10.23939/ep2021.01.007

Received: 2.11 .2020

(C) Krusir G., Sagdeeva O., Tsykalo A., Vilhovska Yu., Shpyrko T., 2021

\begin{abstract}
One of the areas of waste disposal of fermentation industries is anaerobic fermentation and biogas production, which becomes increasingly attractive for researchers not only because of the global energy crisis but also the environmental one. Biogas production is based on methane fermentation fundamentally different from other types of fermentation, which creates certain difficulties in its implementation on a large scale. Therefore, the development of innovative energy and resourcesaving technologies for the processing of liquid waste from fermentation industries is an urgent task for the development of the domestic food industry.

The aim of the work is to develop, theoretically substantiate and experimentally test the technology of processing liquid waste from fermentation plants.
\end{abstract}

Key words: grain bard, biogas, liquid waste, fermentation, mesophilic and thermophilic mode.

\section{Introduction}

The country's economy transition to sustainable development determines the solution of a number of important priority economic tasks, among which the disposal of technological waste of industrial enterprises is environmentally important.

Utilization of technological waste of the food industry has its own features. Technological waste from processing at the relevant enterprises accumulates in enormous quantities. Possessing the same components as the initial raw material, technological waste is, on the one hand, a valuable raw material for further processing into food and feed additives and products, and, on the other hand, it activates the microflora and enzymes, which lead to rapid deterioration. The current pace of the food industry development and the corresponding waste accumulation is such that the lack of implemented technologies for their utilization poses a significant threat to the environment. This is due, first of all, to the rapid development of decay and fermentation processes, the products of which poison the atmosphere, soils and water bodies. With sharp and mass receipt of such waste into environment the balance of microorganisms, including pathogenic kinds is broken.

Based on the analysis of literature sources (Kukharenko, Vynarov, 2001; Ryabov, 2003; Halkina et al., 2014) it should be noted that in the spirit industry the following types of fermentation are mostly used: spirit fermentation, methane propionic and butyric acids. The main type of raw material in fermentation industries is a plant one-potatoes, cereals, sugar beets and cane, various types of molasses.

The main liquid waste is post-alcohol grain bard, the yield of which at an alcohol strength of $6 \%$ vol. is $18.8 \mathrm{dal} \mathrm{bard} / \mathrm{dal}$ alcohol. For an approximate calculation of the grain bard yield set an average of 13 dal to 1 dal of alcohol daily productivity. In fact, at a distillery with a capacity of 3.000 dal, up to $350 \mathrm{~m}^{3} /$ day of bard is formed, the soluble part of which may contain substances with a chemical oxygen demand (COD) of more than $60.000 \mathrm{mg}$ $\mathrm{O}_{2} / 1$.

Grain bard is a polydisperse system in which dry substances are in the form of suspensions or in a dissolved state. It contains up to $92 \%$ water and up to $8 \%$ dry

For citation: Krusir G., Sagdeeva O., Tsykalo A., Vilhovska Yu., Shpyrko T., 2020. Improvement of purification technology of the liquid waste from fermentation production. Journal Environmental Problems. Vol. 6, No. 1. p. 7-14. DOI: https://doi.org/10.23939/ep2021.01.007 
matter and has an acidic reaction ( $\mathrm{pH} 4.2-4.6)$. Bard dry matter comprises proteins, hemicelluloses, cellulose, sugars, dextrins, fat, minerals and other substances. Bard dry matter comprises 35-45\% of suspended solids and $55-65 \%$ of soluble substances.

In the alcohol production from grain raw materials, a significant amount of production waste is generatedpost-alcoholic liquid grain bard which, when discharged into the sewage, causes environmental pollution. At the same time, grain bard has a known nutrition and fodder value, because all the grain protein remains in it after the starchy components are processed into ethanol. Products based on grain bard, containing protein, easily digestible carbohydrates, vitamins, micro-and macronutrients are widely used in agriculture in many countries. With the growth of ethyl alcohol production, including the expansion of its use as a biofuel, the problem of processing post-alcohol grain bard gains greater environmental significance (Shunyayeva et al., 2004; Dvorets'kyy et al., 1998).

Although studies (Dvorets'kyy et al., 1998) have shown that the bard discharge to a certain extent does not cause irreparable damage to the soil filtration fields because, within two months after the discharge, there is a restoration of quantitative and qualitative composition of soil microflora, but with large-scale alcohol production, a valuable product such as animal feed is destroyed. The need to develop a process for bards' processing, as repeatedly noted (Halkina et al., 2014; Lozyns'ka et al., 2002), is caused primarily by environmental considerations by creating low-waste energy and resource-saving industries.

The main difficulties in the disposal of post-alcoholic grain bard are the soluble substances processing [7, 8]. In fact, at a distillery with a capacity of 3.000 dal, up to $350 \mathrm{~m}^{3} /$ day of bard is formed, the soluble part of which may contain substances with a COD of more than $60.000 \mathrm{mg} \mathrm{O}_{2} / 1$. Currently, there are several common areas of postalcohol grain bard processing. All of them are based on the principles shown in Fig. 1 (Porivnyannya tekhnolohiy..., 2020).

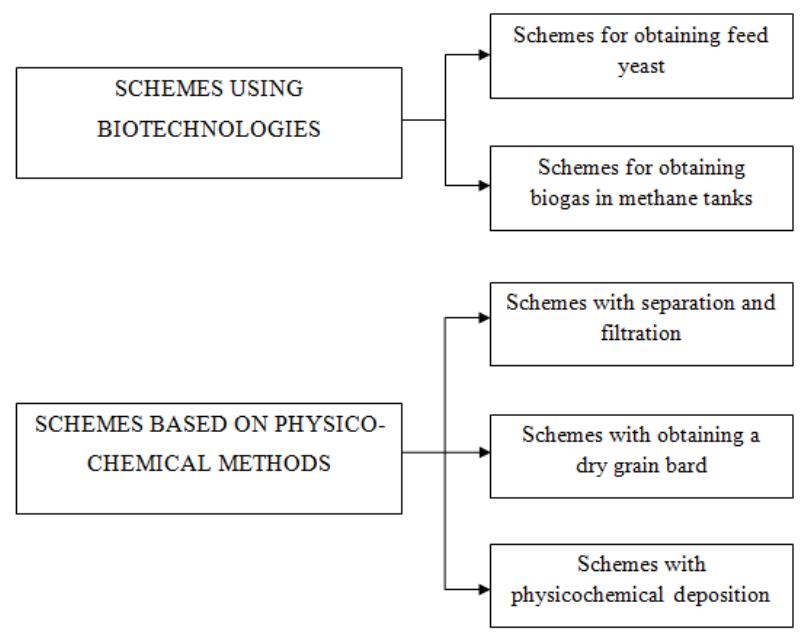

Fig. 1. Schemes of post-alcoholic distellire stillage utilization

When choosing a scheme for the implementation in production, it is necessary to know the advantages and disadvantages of each one. At this time, in most cases, a combination of certain schemes is used [10]. The main difficulty in the post-alcoholic grain bard disposal is the processing of soluble substances. At present, there are several areas for processing post-alcoholic grain bard: with the production of feed yeast; with evaporating stations and drying (DDGS); with biogas production. All these methods can reduce both the total amount of waste while reducing their humidity and energy consumption for their processing. Despite the difference in technology and equipment, the plants have mainly implemented and operated two options for grain bard processing into dry feed products: feed yeast and dry grain bard. In the end, the choice of technology for grain bard processing depends on the production specifics, considering comparative analysis from Table 1, according to (Ledenev, 2008).

Table 1

\section{Comparative analysis of existing technologies for grain bard processing on a 5-point scale}

\begin{tabular}{|c|c|c|c|c|c|}
\hline $\begin{array}{c}\text { Grain bard processing } \\
\text { technologies }\end{array}$ & $\begin{array}{c}\text { Energy } \\
\text { efficiency }\end{array}$ & $\begin{array}{c}\text { Cost of } \\
\text { implementation } \\
\end{array}$ & $\begin{array}{c}\text { Cost of operation, cost } \\
\text { of the product }\end{array}$ & $\begin{array}{c}\text { Ease of } \\
\text { operation }\end{array}$ & $\begin{array}{c}\text { Required } \\
\text { production area } \\
\end{array}$ \\
\hline $\begin{array}{l}\text { With the production of } \\
\text { feed yeast }\end{array}$ & •• & $\cdots$ & • & ••• & $\cdots$ \\
\hline $\begin{array}{l}\text { With evaporating stations } \\
\text { and drying }\end{array}$ & • & $\cdots \cdots$ & • & $\cdots$ & $\cdots$ \\
\hline With biogas production & $\bullet \bullet \bullet \bullet$ & $\cdots$ & $\bullet \bullet \bullet$ & $\cdot$ & $\cdot$ \\
\hline $\begin{array}{l}\text { With separation and } \\
\text { filtration }\end{array}$ & ••• & •• & •• & •• & ••• \\
\hline $\begin{array}{l}\text { With physicochemical } \\
\text { deposition }\end{array}$ & ••• & •• & • & •• & •• \\
\hline
\end{tabular}


In the construction of new plants, preference should be given to waste disposal schemes integrated into the main technological process, such as fermentation in a vacuum or a combined scheme. In enterprises with obsolete equipment (or those that have cheap energy sources), the method of processing to get DDGS or feed yeast should be considered. The scheme for the biogas production should be used by enterprises that are experiencing energy shortages, located far from the main pipelines. Small enterprises need just cattle farms or several filtration fields. Only one thing is clear-according to the accepted norms, there should not remain enterprises without these or those means of grain bard utilization. Thus, despite the scientific progress, the problem of waste disposal of existing industries remains quite relevant.

\section{Experimental part}

The purpose of experimental research is to confirm and clarify the developed theoretical provisions, as well as the compliance of operation parameters and technical means modes of complete utilization of postalcoholic grain bard with the use of anaerobic fermentation technology.

Biogas is formed as a result of the natural process of microbial decomposition of organic matter in a humid environment under anaerobic conditions (in the absence of oxygen). In the fermenter (bioreactor), the bacteria found in nature cause the organic matter fermentation similar to that occurring in the scars of ruminants. Similar processes occur, for example, at the bottom of reservoirs, in swamps or manure pits (Ledenev, 2008; Sposob oderzhanyy biohazu..., 2020; Sposob otrymannya biohazu..., 2020; Baader, Doni, 1982).

The weakness of anaerobic fermentation is the low rate of biomass processing and the relatively low quality of the produced biogas. The process is quite unstable and capricious, which especially depends on the applied temperature of fermentation (Baader, Doni, 1982).

There are three temperature regimes to optimize this process (Baader, Doni, 1982), such as psychrophilic conditions (up to $20-25^{\circ} \mathrm{C}$ ), mesophilic mode $\left(25-40{ }^{\circ} \mathrm{C}\right.$ ) and the thermophilic one (more than $40{ }^{\circ} \mathrm{C}$ ).

It should be noted, that the higher is the temperature of the fermentation process, the more stringent the requirements for the permissible limits of temperature fluctuations for optimal gas formation.

- at the psychrophilic temperature mode $- \pm 2{ }^{\circ} \mathrm{C}$ per hour;

- mesophilic - $\pm 1{ }^{\circ} \mathrm{C}$ per hour;

- thermophilic $- \pm 0.5^{\circ} \mathrm{C}$ per hour. (Ledenev, 2008; Baader, Doni, 1982).

Depending on the type and quality of raw material that is planned to be used to produce biogas, as well as on different needs, the options for bio-energy plants can be quite different. First of all, the timely supply of raw material is required for stable operation of a bio-energy unit (BEU) (Blyum, et al., 2010; Kyurchev, et al., 2012).

The anaerobic fermentation process, with the biogas release, is conventionally divided into four phases according to the type of processes that occur. This is the phase of hydrolysis, acidogenesis, acetogenesis and methanogenesis. Each phase has its own type of bacteria. In the hydrolysis phase, bacteria break down proteins, fats and carbohydrates into simpler molecules, such as sugars, amino acids, etc. In the acidogenesis phase, various organic acids are formed. In the acetogenesis phase acetic acid is formed, and in the methanogenesis phase biogas is formed. This description of the phases is quite figurative, and each phase is described by many chemical equations. Several different reactions can occur simultaneously in each phase. The quantitative ratio of these reactions depends on the type of raw material being processed, the types of bacteria involved at this stage and many other factors. Therefore, it is impossible to accurately calculate and predict the nature of the reaction and quantitative indicators at the output.

Bacteria that work in the first two phases function more efficiently at psychrophilic temperatures. Therefore, there is a technology of two-stage anaerobic fermentation when the reactions take place in two seriesconnected tanks. In the first tank, there are two first phases of anaerobic fermentation at ambient temperatures. The third and fourth phases take place in the second tank at a temperature of $37-38{ }^{\circ} \mathrm{C}$ (Kutsenko, Kolomyts, 2011). However, many researchers note that the same bacteria adapt to different temperatures and can work in different metabolic modes (Krusir et al., 2020).

Experimental studies were conducted on the laboratory equipment, the design of which provided the estimation of the operating processes of biogas plants under different modes of anaerobic fermentation of postalcoholic grain bard.

The process of the grain bard and supernatant anaerobic processing was modelled in a bioreactor of the periodic action with a volume of $\leq 1 \mathrm{~m}^{3}$, operating in mesophilic $\left.(30 \pm 0.5){ }^{\circ} \mathrm{C}\right)$ and thermophilic $\left.(50 \pm 0.5){ }^{\circ} \mathrm{C}\right)$ modes and equipped with the devices measuring the volume of the produced biogas. In this case, BEU was presented as an option-a device for heating the fermented substrate. accepted:

The following program of experimental researches is

1. To inoculate 1 litre of post-alcoholic grain bard with concentrated anaerobic activated sludge for its preliminary accumulation.

2. To carry out experiments in mesophilic and therophilic periodic modes, using a small-volume methane 
tank $\left(\mathrm{VM} \leq 1 \mathrm{~m}^{3}\right)$, cylindrical one with a conical bottom, a side-loading pipe, and a mechanical stirrer. The study period is 60 days.

3. To study the chemical composition of postalcoholic grain bard before and after anaerobic fermentation.

4. To carry out deep purification of the grain bard liquid fraction (BLF) purified in the bioreactor with organic contaminants of the residual COD concentration

5. To study the chemical composition of BLF in accordance with GOST 2874-82 and DSanPiN 2.2.4-171-10.

The program of experimental research provides for the collection of the necessary statistical information to solve the optimization problem, substantiation of the optimal parameters of the BEU technical means. The main tasks of experimental research are verification of theoretical principles and statements that determine the nature and structure of design processes; assessment of the adequacy of the developed models in the parameter optimization of the proposed technical solutions and the experimental confirmation of their effectiveness.

The selected research methods of qualitative and quantitative structure of the post-alcoholic grain bard utilization will allow estimating the course of the basic changes which will occur while using the technology of its anaerobic fermentation with the subsequent purification of BLF as much as possible.

The specifics of the anaerobic liquid waste fermentation process from fermentation plants allows us to consider the formalized relationships of the process taking place in the working space of methane tanks, with the properties of post-alcohol grain bard, design parameters, and their impact on the quality of the finished product such as biogas. The methodology of forming quality indicators depends on the specific process features.

The development of effective technology with quality indicators includes several technological approaches, namely: development of technology for anaerobic utilization of post-alcoholic grain bard and deep purification of the grain bard liquid phase.

Using this methodology will allow us to get:

- biogas with the possibility of its actual use instead of natural gas for the technological needs of the enterprise;

- purified water, from the utilization of grain bard in the volume of the liquid phase, with its return up to $80 \%$ for the production and technical needs of the enterprise;

- dry sludge suitable for the use as a feed additive for domestic animals;

- thermal energy obtained by cooling the original bard.
The research methodological basis on the process of the post-alcoholic grain bard anaerobic utilization in $\mathrm{BEU}$ is the base of a multi-stage and multi-link structure which includes:

- research of the technological process taking place in BEU for the development of a dynamic model of technology;

- research of qualitative indicators of the postalcoholic grain bard utilization;

- deep purification of the grain bard liquid phase.

The research methodological base includes a parametric complex and an experimental series. The parametric complex includes studies of the technological process: the degree of organic matter decomposition in the post-alcoholic grain bard depending on the fermentation temperature.

The experimental series includes:

1) study of the dependences of methanogenic microorganisms' growth and production and the metabolism product formation;

2) determination of the expected biogas volume depending on the fermentation temperature.

3) laboratory tests such as determination of the chemical grain bard composition (the content of reducing carbohydrates, protein, fats, fibre, dry matter, suspended solids) and determination of the BLF parameters (colour, $\mathrm{pH}, \mathrm{COD}, \mathrm{BOD})$.

The proposed complex technology of grain bard utilization (at the initial COD of $60-80 \mathrm{~g} / \mathrm{l}$ ) includes the following main stages of the technological process:

- collection of the original bard and preliminary acid grain bard fermentation within 12-16 hours at the acidogenic bacteria expense. There is the simultaneous settling of the dense grain bard part;

- filtration of the dense grain bard part on mesh drum filters with a mesh porosity of $1.5 \mathrm{~mm}$ with the separation of pellets from the BLF;

- cooling of the BLF to $40-60{ }^{\circ} \mathrm{C}$;

- collection and alkalization of the cooled BLF to $\mathrm{pH}=6.0$, that is a isopotential point of the dissolved amino acids bulk in order to maximize their conversion into insoluble colloids;

- dehydration of the BLF on press filters with membrane filter plates, which allow obtaining a dewatered sludge with humidity up to $40-50 \%$, and deeply purified from suspended solids BLF filtrate with a concentration of organic contaminants for COD up to 15-20 g/l;

- drying of the dehydrated grain bard part and filtered pellets to get a feed product on vacuum ceramic low-temperature infrared dryers or disk dryers;

- methane fermentation of the grain bard filtrate in an anaerobic bioreactor using specially selected types of microorganisms that activate fermentation processes and reduce the duration of the fermentation of dissolved organic substances; 
- illumination of treated effluents in bioreactors on high-speed shelf settlers with the reuse of settled sludge in bioreactors;

- additional treatment of the effluents clarified on the settling tanks by the method of galvanocoagulation and spinel ferritization with the subsequent settling and sorptionmechanical filtration to the level of contaminants at $\mathrm{COD}=30-50 \mathrm{mg} / \mathrm{l}$;

use of $80 \%$ of water after additional purification for technical needs of the plant (feeding of the equipment cooling system, the technological equipment washing, etc.);
- discharge of $20 \%$ of treated water into the city sewerage system with indicators of the main pollution corresponding to the MAC.

\section{Results and Discussion}

Studies of the composition of the original postalcoholic grain bard show (Table 2) that the dry matter of the bard is represented by $50.90 \%$ of suspended solids, which contain mainly protein and fibre. The presence of these substances, as described earlier, slows down the process of anaerobic decomposition of organic grain bard components.

The composition of the original wheat post-alcohol grain bard and filtrate

Table 2

\begin{tabular}{|l|c|c|}
\hline \multicolumn{1}{|c|}{ Indicator } & \multicolumn{2}{c|}{ Value } \\
\cline { 2 - 3 } & The original grain bard & Filtrate \\
\hline $\mathrm{pH}$ & 4.4 & 5.2 \\
\hline Dry matter, \% & 9.47 & 3.54 \\
\hline Suspended solids, \% & 4.82 & 0.31 \\
\hline Solutes, \% & 4.18 & 3.23 \\
\hline Reducing substances, after hydrolysis with HCl, in terms of glucose, \% & 0.45 & 6.39 \\
\hline Crude protein, \% & 19.6 & 4.78 \\
\hline Crude fat, \% & 7.35 & 5.45 \\
\hline Crude fiber, \% & 11.2 & 39000 \\
\hline COD, mg/l & 67000 & - \\
\hline $\begin{array}{l}\text { The amount of wet pellets, \%, by weight of the grain bard separated on the sieve: } \\
\text { - with a hole size of 1 mm } \\
\text { - with a hole size of } 2 \mathrm{~mm}\end{array}$ & 23.1 \\
\hline $\begin{array}{l}\text { The dry grain bard matter content, \%, separated on a sieve: } \\
\text { - with the hole size of } 1 \mathrm{~mm} \\
\text { - with a hole size of } 2 \mathrm{~mm}\end{array}$ & 15.2 \\
\hline $\begin{array}{l}\text { The amount of wet sludge formed by settling the filtrate for 12 h, \% of the volume } \\
\text { of the filtrate }\end{array}$ & 12.6 \\
\hline
\end{tabular}

In the thermophilic regime, the total volume of the formed biogas was $0.149 \mathrm{~m}^{3}$ per 1 dal of grain bard filtrate, which is 1.2 times more than in the mesophilic regime (Table 2).

At the next stage of research, the process of grain bard filtrate anaerobic fermentation in a bioreactor of batch action in the microorganisms' presence that grow spontaneously in mesophilic $\left(30^{\circ} \mathrm{C}\right)$ and thermophilic $\left(50{ }^{\circ} \mathrm{C}\right)$ conditions was modeled.

Fig. 2 shows the daily biogas release in the process of anaerobic fermentation of the filtrate of post-alcoholic grain bard under mesophilic and thermophilic regimes.

As evidenced by the results obtained in the first 8 days as for the thermophilic regime, the destruction of raw material without methane production takes place. As for the mesophilic regime, the time of appearance of methane in biogas was 11 days. The mesophilic regime is characterized by a prolonged hydrolysis process, so this sample requires a longer fermentation period. During this period, only $\mathrm{CO}_{2}$ is released. Starting from the 10th day of thermophilic and from the 16th day of mesophilic regimes, the methane content in biogas is $48 \%$ and reaches a maximum of $68 \%$ on the 14th and the 19th days of fermentation, respectively. In the conducted researches (Fig. 2), in 60 days of the substrate endurance in the mesophilic mode $\left(30^{\circ} \mathrm{C}\right)$, the process of the dry matter decomposition almost reached a maximum in 53 days, and at thermophilic $\left(50^{\circ} \mathrm{C}\right)$ in 46 days.

The obtained data on the degree of the dry matter conversion of the grain bard filtrate by anaerobic microorganisms (Table 3) show the advantage of the thermophilic regime in terms of the process rate over the mesophilic one. Thus, during the thermophilic fermentation of bard filtrate, the COD index is reduced by $84.35 \%$ (against $68.2 \%$ for the mesophilic one), which greatly simplifies the task of subsequent purification of the fermented solution. 


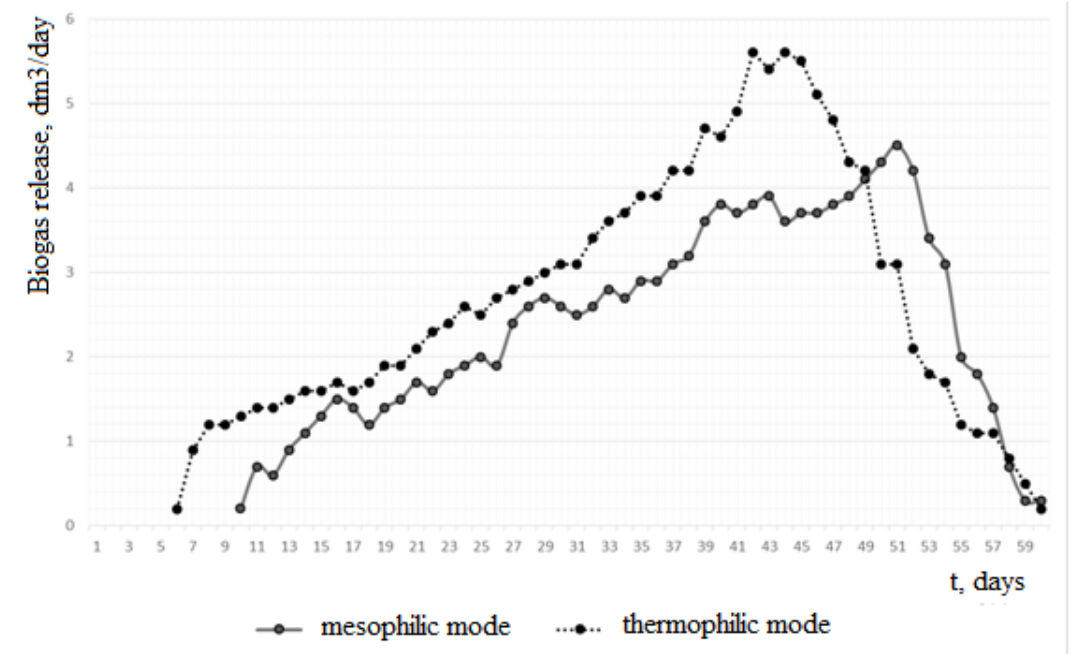

Fig. 2. Daily release of biogas $(\mathrm{V})$ in the process of anaerobic fermentation $(\mathrm{t})$ depending on the temperature regime

Anaerobic fermentation of bard filtrate in a batch bioreactor (duration 60 days)

Table 3

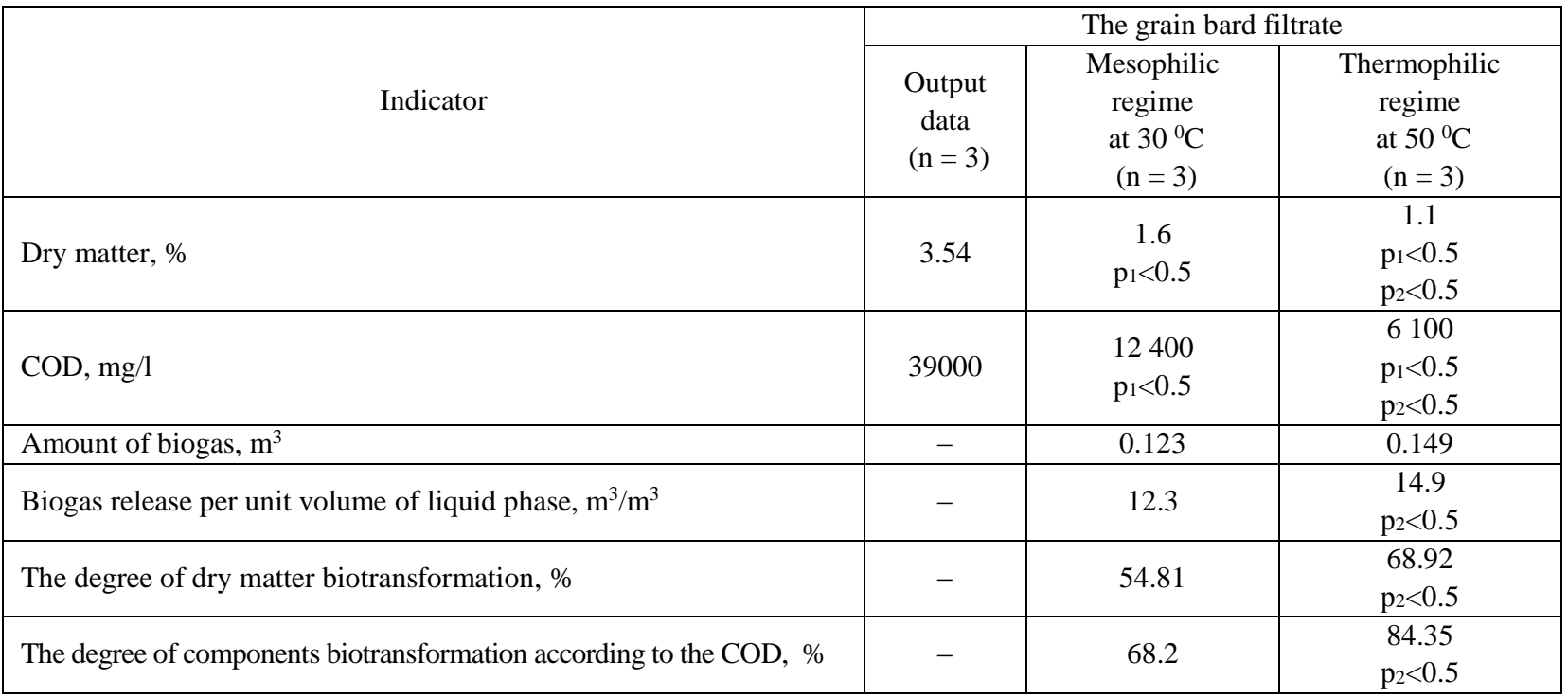

Note: $\mathrm{p}_{1}<0.05$ - comparison with the original data; $\mathrm{p}_{2}<0.05$ - comparison of modes with each other

The obtained data indicate that anaerobic fermentation of grain bard filtrate is expedient for rational use of bard components.

After the fermentation process, the liquid from the methane tank was drained into a settling tank, where the clarified effluent in the bioreactor was purified on shelf settlers with the possibility of reuse of the settled sludge in the bioreactors during cyclic production.

Studies of the composition of the native postalcoholic grain bard show that the grain bard dry matter is $50.90 \%$ represented by suspended solids, which contain mainly protein and fiber. These substances significantly inhibit the process of liquid substrate anaerobic conversion. We consider that it is possible to get rid of the negative effects of inhibition through the introduction of the stage of the grain bard preacidification.

After purification of the fermented solution (thermophilic regime) using a shelf settler, a clarified solution with a concentration of residual organic substances at $\mathrm{COD}$ of $1.73 \mathrm{~g} \mathrm{O}_{2} / 1$ was obtained. The degree of purification of the born solution in the settling tank averages is $80 \%$.

With the use of galvanocoagulation and spinel ferritation, purified water with the indicators of the main contaminants with the concentration of residual organic substances at the COD of $0.42 \mathrm{~g} \mathrm{O}_{2} / 1$ was obtained. The degree of the last stage of purification is 
$75 \%$. Based on the characteristics of the physicochemical composition of wastewater, it can be concluded that it meets the requirements of GOST 2874-82 and DSanPiN 2.2.4-171-10 and does not pose a threat to surface water.

\section{Conclusions}

The main liquid waste of alcohol production is post-alcohol grain bard, the main difficulty in the disposal of which is the processing of soluble substances. The paper presents the results of testing the technology of liquid waste treatment of fermentation plants and proves the effectiveness of its use.

To improve the technology of liquid waste treatment of fermentation plants, the following tasks have been solved:

- the main technological stages of obtaining postalcohol bard, its chemical composition and existing processing technologies are characterized;

- the technology of processing post-alcoholic grain bard using anaerobic fermentation is developed and theoretically substantiated;

- the technological parameters of processing post-alcoholic grain bard and secondary fermentation products in the process of anaerobic fermentation are experimentally tested;

- the qualitative and quantitative composition of post-alcohol grain bard processing products, at the main stages of the experimentally modelled technological process and the degree of wastewater treatment have been studied.

An effective technology with quality indicators which meets the requirements of state standards and includes several technological approaches was developed. It allows getting biogas with the possibility of its actual use for the technological needs of the enterprise; purified water with its return up to $80 \%$ for production and technical needs of the enterprise; dry sludge to be used as a feed additive; thermal energy obtained by cooling the original bard.

In the thermophilic regime, the total volume of formed biogas was $0.149 \mathrm{~m}^{3}$ per 1 dal of bard filtrate, which is 1.2 times more than in the mesophilic regime. The degree of the dry matter conversion of the grain bard filtrate by anaerobic microorganisms revealed a significant advantage of the thermophilic regime in terms of rate and quality of the process over the mesophilic one, which greatly simplifies subsequent purification of the fermented solution. After purification of the fermented solution (thermophilic regime) using a shelf settler, a clarified solution with a concentration of residual organic substances at $\mathrm{COD}$ of $1.73 \mathrm{~g} \mathrm{O}_{2} / 1$ was obtained. The degree of purification of the fermented solution in the settling tank averages is $80 \%$. With the use of galvanocoagulation and spinel ferritation, purified water was obtained with indicators of basic pollution with a concentration of residual organic substances at COD of $0.42 \mathrm{~g} \mathrm{O}_{2} / 1$; it does not pose any threat to surface waters according to physicochemical parameters.

\section{References}

Dvorets'kyy, S. I., Dolhunin, V. N., \& Zyuzina O. V. (1998). Rozrobka teoretychnykh osnov rozrakhunku i konstruyuvannya enerho- i resursozberihayuchoho obladnannya mnohoassortymentnoy khimichnykh i mikrobiolohichnykh vyrobnytstv. Zb. nauch. tr. Tambo. derzh. tekhn. un-tu, 14-27. [in Ukrainian]

Baader, V. \& Doni, E. (1982). Biohaz: teoriya i praktyka. Moskva: Kolos. [in Russian]

Blyum, Ya. B., Heletukha, H. H., \& et al. (2010). Novitni tekhnolohiyi bioenerhokonversiyi. Kyiv: Ahrar Media Hrup.

Halkina, H. V., Illarionova, V. I., Volkova, H. S., Horbatova, Y. V., \& Kuksova E. V. (2014). Nova tekhnolohiya pererobky pislyaspyrtovoyi bardy. Likero-horilchani vyrobnytstvo $i$ vynorobstvo, (6), 14-16. [in Ukrainian]

Kukharenko, A. A., \& Vynarov, A. Yu. (2001). Bezvidkhidna biotekhnolohiya etylovoho spyrtu. Moskva: Vyshcha shkola. [in Russian]

Kutsenko, Yu. M., \& Kolomyts, V. M. (2011). Analiz osnovnykh chinnikiv anaerobnoho metanovoho zbrodzhenykh dlya Otrymannya biohazu. Pratsi TDATU. Melitopol': TDATU, 11(30), 49-56. [in Ukrainian]

Krusir G., Sagdeeva O., Malovanyy M., Shunko H., Gnizdovskyi O. (2020). Investigation of Enzymatic Degradation of Solid Winemaking Wastes. J. Ecol. Eng. 21(2):72-79. doi: https://doi.org/10.12911/22998993/ 116345

Kyurchev, V. M., Didur, V. A., \& Hrachova, L. I. (2012). Al'ternatyvne palyvo dlya enerhetyky. V. A. Didura (red.). Kyiv: Ahrarna osvita. [in Ukrainian]

Ledenev, V. P. (2008). Pererobka bardy: dosvid, real'nist', perspektyvy. Likerovodoch. vyrobnytstvo i vynorobstvo, (7), 8-11. [in Ukrainian]

Lozyns'ka, T. I., Khudyakova, N. M., \& Likhterberh, L. A. (2002). Vyrobnytstvo kormovykh drizhdzhiv iz pislyaspyrtovoyi zernovoyi bardy po bezvidkhodnoyi tekhnolohiyi. Likerohorilchani vyrobnytstvo $i$ vynorobstvo, (7), 1-3. [in Ukrainian]

Novykov, V. B., \& Zvyeryev, S. V. (2007). Barda v zakoni. Vyrobnytstvo spyrtu ta likero-horilchanykh vyrobiv, (2), 20-23. [in Ukrainian]

Porivnyannya tekhnolohiy pererobky bardy, pererobka pislyaspyrtovoyi bardy. (2020). Retrieved from http://www.spbarda.ru 
Ryabov, H. K. (2003). Systema bezvidkhodnoyi pererobky pislyaspyrtovoyi bardy. Innovatsiyi: Doslidzhennya $i$ rozrobky, (6), 12-17. [in Ukrainian]

Shunyayeva, O. B., Malakhova, N. A., \& Hrydnyeva, L. T. (2004). Dynamika zminy mikroflory poliv fil'tratsiyi. Pratsi Tambo. derzh. tekhn. un-tu, (15), 78-82. [in Ukrainian]

Sposob oderzhanyy biohazu ta biodobriv z orhanichnikh vidkhodiv: opysanye do patentu na korysnostey model'. (2020). Retrieved from http://uapatents.com/3-52419sposib-oderzhannya-biogazu-ta-biodobriv-z-organichnikhvidkhodiv.html
Sposob otrymannya biohazu: opysanye do patentu na korysnostey model'. (2020). Retrieved from http://uapatents.com/483722-sposib-otrimannya-biogazu.html

Tekhnolohichna liniya $z$ osushennya bardy, vprovadzhena na Urzhums'komu SVZ Kirovs'koyi oblasti i pryznachena dlya otrymannya sukhoyi pislyaspyrtovoyi bardy $v$ vyhlyadi poroshku i hranul. (2020). Retrieved from www.distil.ru

Zyuzina, O. V., Hrachova, I. M., \& Arzamastsev, A. A. (1990). Osnovy biotekhnolohiyi ta promyslovoyi ekolohiyi. Tambov: Tambo. in-tu khim. mashynobuduvannya. [in Ukrainian] 